\title{
The Reform Feasibility of the English Course Based on CBI in the Vocational and Technical Colleges in China
}

\author{
Ji Zhenghong \\ Foreign Languages Department. \\ Taizhou Vocational \& Technical College \\ Taizhou, China \\ e-mail: kathysd_77@163.com
}

\begin{abstract}
This paper begins with the development tendency and the present situation of the English course in the vocational and technical colleges in China, which shows the necessity of the reform. With the guide of the Input Hypothesis by Krashen and Learning Motivation Theory by Gardner, the author demonstrates the feasibility and the significance of the English course based on CBI.
\end{abstract}

Keywords-CBI; reform of the English course; feasibility; theoretical support;

\section{INTRODUCTION}

Nowadays, with the further development of reforms in the vocational and technical college, the English course, as a pure language course, is marginalizing and meeting great challenges. The English course has been dismissed or the English teachers have been assigned to other departments. The challenges that the English course meets show that the reform must be implemented..

\section{THE REFORM NECESSITY OF THE ENGLISH COURSE.}

A. the development tendency of the higher vocational and technical education.

The cultivation aim of the higher vocational and technical education is to cultivate the vocational and technical oriented people, so the model of work-study combination which advocates that learning is working and working is learning can meet the development of the higher vocational and technical education. Under this model, the students can be more capable in working area, compared with the four-year students. As one of the courses, the English course should also meet the development of the higher vocational and technical education and cultivate the students' vocational proficiency in the daily classes.

$B$. the present situation of the English course in vocational and technical colleges

Why the English course is marginalizing? The reason lies in the layout of the English course. The content of the English course in the vocational and technical colleges stills keeps the characteristics of the four-years students' teaching content, which focuses more on human and art. The English in the vocational and technical colleges only add some practical skills on listening, speaking, which makes it a little different from the English course in the four-year colleges and makes it has the characteristics of higher vocational and education. Yet, most of the students have been learning
English since their childhood, and they have got a large vocabulary and have got some basic listening, reading and writing skills. The vocabulary in the English course in vocational and technical colleges is lower than that in their higher school, which makes the students less active in class. According to a survey, $80 \%$ of the students in vocational and technical colleges show little interest in college English study, and they think the college English is very easy, and they think their study purpose is to find a job after graduation while English seems to be helpless to their professional development.

Both the development of the higher vocational educational and the present situation of the English course require the reform, so the reform of the English course must be implemented.

\section{THE INTRODUCTION TO CBI}

CBI(Content-based Instruction)comes from the immersion class in Canada in the 1960s. With the success of the immersion class, the ESL and EFL researchers show interest in the teaching model of CBI, and they all put it into practice in their own country and also made great success. The success of the immersion class demonstrates the feasibility of CBI, and CBI is more and more popular in the ESL teaching in the world.

The teaching model of CBI is based on subject matter, and combines the language study with the subject study, which make the language teaching focuses not on the language itself but the subject. The students may improve English skills through the study on subject matter. Through the English course, the students both can acquire the English language and subject matter. CBI makes English becomes a real language tool.

From the 1970s to 1980s, CBI came into China, yet not became popular. Some Chinese educators such as Cai Jian(2002), Yu \& Han(2003), Yuan Pinghua(2006,2008 etc.) Chang Junyue(2008) made further discussion on CBI and they also made some empirical study on CBI. Yet all the above discussion and study focus on the English courses in four-year colleges, and recently the application of CBI on English course have been implemented in Dalian Foreign Studies University and Nanchang University. Shang Weixia(2010) made the empirical study in a vocational and technical college. There is little study on CBI in vocational and technical colleges, so this paper focuses on the theoretical study on CBI in vocational and technical 
colleges, and the empirical study will be carried out step by step.

\section{THE IMPLEMENTATION SIGNIFICANCE OF THE CBI IN ENGLISH COURSE IN VOCATIONAL AND TECHNICAL COLLEGES.}

A. to the teachers: the English course is a traditional course in China, and more and more English teachers find that the students are not active in class. CBI is new, and it has four models: sheltered model, adjunct model, themebased model and language for special purposes. The English teachers may choose one model and put it into class activity. Since CBI focuses on subject matter, the students' enthusiasm will be improved.

B. to the students: in the teaching model of CBI, English is used as a language tool to deliver the knowledge on subject. What the students learn is subject matter or topics that they are interested in, so the students may show great interest in class, and their enthusiasm and participation in class will be greatly improved.

C. to the English course: with the guidance of CBI, the English course is not a pure language course, but makes English a tool to deliver some knowledge. This model changes the traditional model in which language is learned through language. CBI model may change the traditional English course, and combine language and subject matter, makes the English language find it real identity.

D. to the other majors in vocational and technical colleges: CBI advocates the combination of language and subject, so the students may learn both the language and subject matter. After the study the students may use English to search the international advanced technology, which may promote the internationalization of the other majors in vocational and technical colleges.

\section{THEORETICAL SUPPORT OF THE ENGLISH COURSE BASED ON CBI}

The theoretical support of the English course based on CBI comes from the Input Hypothesis by Krashen and the Learning Motivation Theory by Gardner.

\section{A. the Input Hypothesis by Krashen}

The Input Hypothesis is at the core of modern language acquisition theory, which is also regarded as the key theory of second language acquisition. Stephen D. Krashen(1985) put forward five hypothesis in his book The Input Hypothesis: Issues and Implications. The five hypotheses are the acquisition-learning hypothesis, the natural order hypothesis, the monitor hypothesis, the input hypothesis, the affective filter hypothesis.

In the acquisition-learning hypothesis, Krashen thinks that the learning of language is a conscious process, while the acquisition of language is a subconscious process. In English class based on CBI, the students acquire the language through subject matter. The acquired knowledge is the source of comprehension and communication. In practice, the acquired language may help the students understand and communicate the subject matter.
The natural order hypotheses states that a language is acquired in roughly the same order. The English course based on CBI is also designed in the natural order according to the subject, which is in accordance with the second language acquisition.

When dealing with output, learning and acquisition has different functions. The monitor hypothesis asserts that a learner's learned system acts as a monitor to what they are producing. Utterance comes from subconscious language learning, while the conscious language learning may result in self-monitoring. The English course based on CBI makes the students have plenty of time to learn subject matter, while the students don't have time to learn subject matter in traditional English course. Such subconscious learning may help the students' language output. And the grammar rules which have grasped since middle school may help monitor. The English course based on CBI has got the monitor function.

The input hypothesis is the core of input theory, which shows how human learn a language. Krashen put more emphasis on the comprehensible input. Only comprehensible input can be processed by the brain. Krashen put forward the " $\mathrm{i}+1$ " model. " $\mathrm{i}$ " is the language input, and this model states that the comprehensible input must be slightly more advanced than their current level so that the learner may acquire new information. The totally incomprehensible language cannot be input. The English course based on CBI is just followed the input hypothesis. Language study and subject matter are combined, and a large amount of input is not the pure language input, the learning may comprehend language input with the help of subject matter. This input of combination of language and subject matter is a little higher than the pure language input, which is totally in accordance with the input hypothesis by Krashen, and the learner may acquire both the new language knowledge and subject information, which further shows that the feasibility of the English course based on CBI.

In the affective filter hypothesis, certain emotions, such as motivation, anxiety, and self-confidence etc, play an important role in the second language acquisition. The negative emotions, such as anxiety, can prevent efficient processing of the language input, while the positive emotions, such as self-confidence, can promote efficient processing of the language input. In the English course based on CBI, the learners are put into the study of subject matter, and they may feel that they are learning subject matter, so the learners may "forget" that they are learning English, and they cannot feel the pressure coming from the traditional English class. At that time, the filter is the lowest. The lowest the filter is, the most easily the learners may acquire the language.

\section{B. Learning Motivation Theory by Gardner}

Robert C. Gardner is one of the earliest researchers on the motivation of second language acquisition from the socio-psychology. He introduced the notions of instrumental and integrative motivation: Instrumental motivation refers to the learner's desire to learn a language for utilitarian 
purposes while integrative motivation refers to the desire to learn a language to integrate successfully into the target language community. Later he explored four other motivational orientations: (a) reason for learning, (b) desire to attain the learning goal, (c) positive attitude toward the learning situation, (d) effortful behavior. The relationship between the four orientations are as follows: (Figure 1)

Yang Zhenghong etc.(2010)made the questionnaire to survey the purpose of English learning and find that the motivation of most of the students in China is instrumental motivation. The students in vocational and technical colleges have a specified purpose that they need pass the English examination and find a good job after graduation. This specified purpose is the intrinsic motivation. The English course based CBI can stimulate the students' intrinsic motivation. The combination of language and subject matter makes the language serve for subject matter, and the study purpose is specified, and English is just a language tool, and learning English well may offer the students bright future. Learning motivation can promote the enthusiasm of English study. The English course based on CBI can promote the learning motivation.

\section{CONCLUSION}

The English course based on CBI can help solve the present problems that exist in the English teaching, and it is in accordance with the development tendency of the higher vocational and technical education. Both Input Hypothesis by Krashen and the Learning Motivation Theory by Gardner can give theoretical support to the English course based on CBI. Such course also has great significance to the teachers, students, the layout of the course and even the internationalization of the majors. All the above shows the feasibility of the English course based on CBI. Now, the teaching practice has been carried out in two four-year colleges, and it is expected to be implemented in vocational and technical colleges.

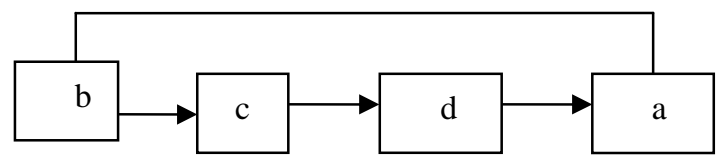

Figure 1.

\section{ACKNOWLEDGMENT}

I would like to extend my deepest gratitude to my supervisor, Mr. Sheng in Zhejiang University, who introduces CBI to me and gives me patient instruction on my papers.

I also give my deep gratitude to Taizhou Vocational and Technical Colleges, which finance me and set up the project with the name of The Reform Feasibility of the English Course Based on CBI in the Vocational and Technical Colleges in China so that I have the opportunity to make further study on CBI. The project Number is 2013YB16.

Last, I should say many thanks to my colleagues, who do me great favor in the study.

\section{REFERENCES}

[1] S. Krashen, The Input Hypothesis: Issues and Implications, New York: Longman, 1985.

[2] R.Gardner and W. Lambert, Attitudes and Motivation in Second Language Learning, Rowley MA: Newbury House Publishers.

[3] Cai Jian, "Study on SLA and CBI model," Journal of Beijing International Studies University, vol. 109, Mar. 2002, pp.13-15.

[4] Chang Junyue, Zhao Xiuli, and Li Lili, "the Discussion on the Feasibility of CBI Implemented in grade 1\& 2 of English majors,” Foreign Language and Their Teaching, vol. 237, Dec. 2008, pp.24-30.

[5] Shang Weixia, "the Empirical Study on CBI in the English Course in Vocational and Technical Colleges,” Journal of Harbin Vocational \& Technical College, May. 2010, pp.26-27.

[6] Yang Zhenghong, Li lihua, and Wang Zhimin, "Gardner's Motivation Model and the Stimulating Strategy in College English Class," Journal of Ningxia University, vol, 32, Jan. 2010, pp. 233-236.

[7] Yuan Pinghua, "the Discussion on the Theoretical Support and the Teaching Model of English Teaching Based on CBI," Academic Degrees \& Graduate Education, Mar. 2006, pp.31-36.

[8] Yu Liming and Han Jianxia, "CBI in Ottawa and its Inspiration,” Foreign Language Teaching and Research, vol. 35, Jun. 2003, pp.465-468. 